\title{
Recovery of Copper Ions from Industrial Wastewater by Electrodeposition
}

\author{
Ayşe Kuleyin* , Hülya Erikli Uysal \\ Ondokuz Mayıs University, Environmental Engineering Department, Samsun, TURKEY \\ *E-mail: akuleyin@omu.edu.tr, ${ }^{1}$ hulya.erikli@ hotmail.com
}

doi: $10.20964 / 2020.02 .39$

Received: 4 October 2019 / Accepted: 25 November 2019 / Published: 31 December 2019

\begin{abstract}
Electrodeposition is an attractive method used for the recovery and removal of metal ions from metal coatings, metal processing and electronic industry wastes. In this study, copper was both removed and recovered from industrial wastewater containing copper by using the electrodeposition method. Two series of experiments were conducted by using copper and stainless steel as cathodes. In both experiments, the effects of current, $\mathrm{pH}$, conductivity and initial copper concentration on the electrodeposition efficiency were investigated, and optimum values were obtained. With this method, the amount of copper removed from industrial wastewater under optimum conditions was $66 \%$ in the experiments conducted with the copper cathode and $80 \%$ in the experiments conducted with the stainless steel cathode. It was also observed as a result of the experiments that the copper removed from the wastewater was deposited on the cathode. In addition, reaction kinetics suitable for the experimental conditions were investigated and generally found to be compatible with a second-order kinetic model.
\end{abstract}

Keywords: electrodeposition, wastewater treatment, copper, recovery, removal

\section{FULL TEXT}

(C) 2020 The Authors. Published by ESG (www.electrochemsci.org). This article is an open access article distributed under the terms and conditions of the Creative Commons Attribution license (http://creativecommons.org/licenses/by/4.0/). 